\title{
Using Documentary Films in Developing Student's Critical Thinking Skill: Senior High School Context
}

\author{
Jumiati Lanta, Suleha Ecca, Asyanti Asyanti, \& M. Hijaz Tahir \\ Universitas Muhammadiyah Sidenreng Rappang. Sidrap. Indonesia \\ jumiatilanta@gmail.com
}

\author{
ARTICLE HISTORY \\ Received : 2019-04-13 \\ Revised : 2019-04-15 \\ Accepted : 2019-06-29
}

\section{KEYWORDS}

Documentary Films Critical Thingking's Skill

High school Students

quantitative study

\begin{abstract}
The quantitative study is aimed to know whether the documentary film can be applied to foster students' critical thinking skills. This research was conducted in class X SMA Negeri 10 Sidenreng Rappang, with a total population of 72 students. Samples were drawn from the entire population by taking 2 classes, namely X IPA 1 as an experimental group of 26 students and X IPS as a control group of 25 students. Data were collected through a critical thinking ability test instrument based on critical thinking indicators, then processed with data analysis using the Mean score (average) and SPSS 2.0. Results of the study showed that experiments group which were taught to use the documentary obtain average value is higher compared with the controls group in fostering the ability to think critically, especially on the subjects of Indonesian with developing materials with the opinion of exposition text. Average score results in critical thinking skills with a documentary film that is 91.76 with the results of a significant test of the test independent of 10.878 while the average score of the results that are taught without using documentary 70.84 with value significant 2,009. Based on the results of data analysis. Therefore, this present study believed that documentary films could foster students' critical thinking skills.
\end{abstract}

\section{Introduction}

The ability to think critically is one of the abilities required where the flow of information is very dynamic. Information can be obtained from anywhere and at any time from various sources are not necessarily able to accounted for righteousness. For that needed the ability to think critically for students. Thinking critically is a skill systematic in assessing, solve a problem, draw conclusions, give confidence, analyzing an assumption, and search scientific. Think critically, including the process of thinking level high, because at the time of taking a decision or conclude using a control active, that is reasonable, reflective, responsible, and skillful thinking. The ability to think critically is very necessary to analyze a problem until the stage of finding a solution to settle the problems mentioned.

One of the ways to cultivate the ability to think students critically that force educators should choose the media that right. By selecting the right media in the learning process, it can change the expressive and creative power of students to be more inclined to think critically so that students can more actively participate in the learning process. The media are appropriate to use in improving the ability to think critically students, namely the application of the film documentary. Film documentary is becoming a tool to help in developing the ability to think critically students so focused on what are displayed or delivered as directly.

Based on the results of observations beginning, see the conditions that occur in schools, especially of subjects Indonesian Language by student class X SMA Negeri 10 Sidenreng Rappang, where teachers just focused to the material that will be presented to the participants of the students, so that students are not able to contribute actively in the implementation of the process of learning to teach. Teachers should be prosecuted how so students can be more active in issuing opinions, ideas, or ideas that can train students to think in critically about what the students get out of the material that is presented when high of critical thinking needed students for the future. In addition to that, to support a process of learning takes an election method or medium that right in accordance with the material or the eyes of subjects that will be delivered. Selection of media appropriate to support the success of students in the growing ability to think critically. One of the media that can foster the ability to think critically is a movie documentary. Film documentary is very effective in growing ability to think students critically because students can see it directly about the 
material that will be delivered without the need to fantasize so teachers can create an atmosphere of learning that is more active and efficient than before.

Critical thinking is very important for the students, in which students have independently put forward ideas, ideas, or opinions in accordance with the material of learning that is delivered. With the growing ability to think critically, encouraging the students is actively in the process of learning to be more effective and efficient.

\section{State of the Art}

\subsection{Critical Thinking Skill}

Critical thinking is a cognitive skill developed through a planned teaching and learning process (Duron, Limbach, \& Waugh, 2006). Critical thinking is thinking reasoned and reflective by emphasizing making decisions about what to believe or do (Ennis: 1989). There are three steps in the critical thinking process, namely the formation of understanding, forming opinions, and concluding.

Ennis ( Maftukhin, 2013: 22) critical thinking is thinking sensibly focused on deciding what to believe and do". From the definition, it can be disclosed something important is to think critically focused to the sense of something full consciousness and lead on a goal. The purpose of critical thinking is to consider and evaluate information that ultimately enables a decision to be made.

Based on the definitions above, it can be understood that what is meant by the ability to think critically is the ability to think logically, reflectively, systematically, and productively which is applied in assessing situations to make good judgments and decisions.

Critical thinking aims to test opinions and ideas, including making judgments based on the opinions put forward. This consideration is supported by the existence of justifiable criteria.

The ability to think critically can encourage someone to find new ideas or thoughts about an existing problem. Someone will be trained to select various opinions so that they can distinguish which opinions are relevant and which are irrelevant, which opinions are correct and which are not. By developing critical thinking skills, one can make conclusions by considering data or sources and facts that occur in the field.

Critical thinking skills are very important to be developed in social life. The low ability to think critically results in frequent gaps or misunderstandings between communities. Critical thinking can change their view of a problem they are facing so that there is no misunderstanding in dealing with an existing problem.
Critical thinking includes the entire process of obtaining, comparing, analyzing, evaluating, and acting beyond science and values. Critical thinking is not just thinking logically, but critical thinking must have beliefs and values, rationale, and belief before getting logical reasons.

\subsection{Media}

The word /media/ comes from the Latin 'medius', which literally means 'middle', 'intermediary' or 'introduction'. Media is an intermediary for messages from sender to message recipient. The type of media used in learning is educational technology (Sayuti, 1985: 232). In this case, the learning media is part of educational facilities that have an important role in teaching and learning activities (Ecca \& Lanta, 2019; Lamalla et al., 2019; Lanta, 2015; Aswadi et al., 2021; Ririantika et al., 2020; Mohammed Ibrahim, 2020)

Learning media in teaching and learning activities are needed in order to teach effectiveness and efficiency. Hamalik (1980: 23), instructional media is a method or technique used to streamline communication and interaction between teachers and students in the educational process. From several explanations about the media, it can be concluded that the media is a learning aid or resource used by teachers to convey messages or information to students to achieve predetermined teaching goals.

Hamalik (1986) argues that media use in the teaching and learning process can generate new desires and interests, generate motivation and stimulation of learning activities, and bring psychological influences on students.

The benefits of media in the learning process are facilitating interaction between teachers and students so that learning can be more effective and efficient (Kemp and Dayton, 1985).

\subsection{Documentary Films}

A documentary film is a film that documents a reality or fact. A documentary film dealing with people, characters, events, and locations was real. The documentary film does not create events or occurrences, but the record of events that truly happened, did not like the movie fiction, the film documentary does not have a plot (a series of events in the film are presented in the audience in visual and audio), but has a structure which is based by theme or argument. The documentary film does not have the character antagonist and protagonist, conflict, and completion as well as movie fiction (Nugroho, 2007).

A documentary film is a form of audiovisual product that tells a daily phenomenon worthy of being appointed as a reflection for the audience. Generally, the material documentary can be a story about the concerns of social, experience life that gives inspiration and spirit alive for the audience about the 
history that ever happened and no relation to the current period (Brata, 2007: 57).

Films that are packaged in accordance with reality, as is known by documentary films, serve to provide an overview of what will be conveyed in the film. The element of delivering the message is poured directly through the film so that people watching the film can stimulate their thinking so that the message conveyed can be digested properly.

Documentary films can be used in learning which are considered quite affordable media. Documentary films can make students remember the material learning better, because it contains visual, audio and dramatic (evocative) elements.

By applying documentary films in the learning process, students do not only listen to the teacher's description, but also other activities such as observing, doing, demonstrating, acting, and others. So it can be concluded that the application of documentary films provides a real picture to students so that they can conclude learning about what is obtained and stimulate students to think critically according to the material presented.

\section{Method}

This study uses a quantitative approach. Research with quantitative methods emphasizes its analysis on numerical data (numbers) processed by statistical methods. Using experiments research aimed at testing the effectiveness of a documentary film in the kind of critical thinking in class X SMA Negeri 10 Sidenreng Rappang.

The research design is a research structure arranged so that the researcher will get answers to research questions (Kerlinger, 2006: 483). To produce a good result or research, the researcher must first make a program or research framework to be carried out, so that the implementation can be systematic and directed and can be completed on time. The design applied in this study is to provide test treatment to the experimental and control groups because in this study control all external variables that affect the course of the experiment. This causes the samples used for experiments and as a control group to be drawn randomly from certain populations.

In this study, the population used was class $\mathrm{X}$ students, namely, X IPA 1, X IPA 2, and X IPS SMA Negeri 10 Sidenreng Rappang, totaling 75 students divided into three classes. In this study, it is assumed that the population is homogeneous because the placement of students in one class is not determined based on student achievement. In this study sampling, the researcher took a sample of two classes from the number of existing classes with a sample of class $\mathrm{X}$ IPA 1 and X IPA 2.

\section{Result}

\subsection{Presentation of data}

The data presented below are the test results in improving the critical thinking skills of students in class X SMA Negeri 10 Sidenreng Rappang. Amounting to 75 students from 3 classes consisting of X IPA 1, X IPA 2 and X IPS as a population and sample. taken only 2 classes, namely X IPA 1 and X IPA 2. Students are given a test of 20 numbers to obtain the score and the extent of the student's ability to think critically.

The test results will be added up based on a predetermined formula with a weighting of 0-5 and the total value of the 20 essay test questions with a maximum score of 100 .

\subsection{Data analysis}

Table 1. Group Statistics

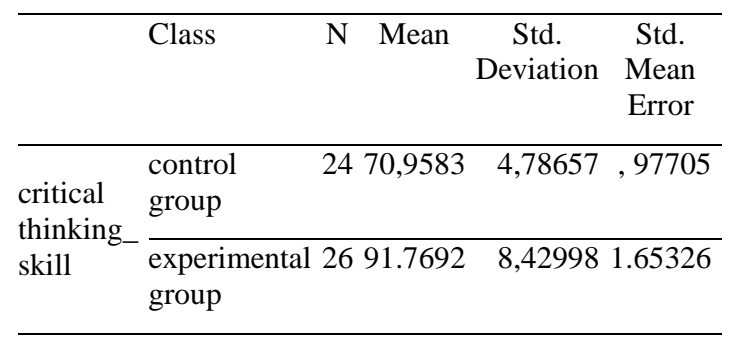

The Output Group Statistics table shows that the number of data on critical thinking skills in class X IPA 2 (control group) is 24 students. In comparison, inclass X IPA 1 (experiment group), there are 26 students. The average value of the results of critical thinking skills or mean to X class IPA 2 (control) for 70,95 while Class X Science 1 (experiment) at 91,76 While the division of each standard 4.7 and 8.4 and the mean, standard error in each class is 0.9 and 1.6. Thus, in the statistic description, it can be concluded that there is a difference in the average results of critical thinking skills in Indonesian language learning with exposition text material in class X IPA 2 and X IPA 1.

In developing good critical thinking skills, it requires awareness and skills that maximize the brain's work through good critical thinking steps so that a critical thinking frame and critical thinking are in good patterns. The application of documentary films is very necessary during the learning process, as was done when testing the experimental class using documentary film media to put forward ideas or opinions according to what students see directly by using documentary films on exposition text material. Students remember the learning material better because it contains visual, audio, and dramatic elements. In contrast to the control class, the learning process takes place without media use so that many students do not focus on learning. 
The result of test that are used as the basis to determine the effectiveness of a documentary film in fostering critical thinking skills of students in the experimental group and the control class that does not implement a documentary. Variables that are used in research this is a variable -free, namely the application of a documentary film, and variable dependent that fosters critical thinking skills of students in class $\mathrm{X}$ SMA Negeri 10 Sidrap. In connection with the methods of engineering decision- value, accumulation test the value of the test as much as 20 number about essay with weight ratings of $0-5$ corresponding provisions to achieve a score of up to 100. Based on the results of the research in accordance with the test, the hypothesis through the analysis of data which is obtained average ability to think critical derived class control is 70, and the average value of the experimental class is 91. While the output of SPSS Independent Sample Test note that the value of $\mathrm{t}_{\text {amounted }}$ to 10.8 three

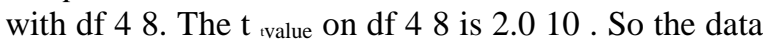
is $10.837>2.010$ then $\mathrm{H}_{\circ}$ rejected and $\mathrm{H}_{1}$ accepted so that it can be said that there are significant differences in critical thinking skills by implementing a documentary film and the conventional method in class X SMA Negeri 10 Sidrap.

This research is in line with research conducted by Winda Ayuningtyas (2015), Novinda Wahyuningsih (2016), and Ambrusius Kuncoro Brahmowisang (2019), testing critical thinking skills using various media in the learning process. So it can be concluded that there are differences in the application of documentary films in fostering critical thinking skills of class X SMA Negeri 10 Sidenreng Rappang . This is shown by the application of documentary films that can effectively foster critical thinking skills so that students are more free to express ideas or opinions in Indonesian subjects. As for the factors that affect the lack of critical thinking skills of students because the teacher does not use a medium in the learning process, one of which is documentary film media. The use of documentary film media can facilitate the learning process by presenting events or events that occur in accordance with the subject of the exposition text. Based on the facts that, then the hypothesis of work or hypotheses alternative that "the implementation of the documentary effective in fostering critical thinking skills class X SMA Negeri 10 Sidenreng Rappang the teachings of 2020 /2021" acceptable. While the hypothesis of zero or nil states that: "the implementation of the documentary is not effective in fostering students' critical thinking skills class X SMA Negeri 10 Sidenreng Rappang the teachings of 2020 /2021", was rejected.

\section{Conclusion}

The results of the seen several things that that need to be highlighted as a conclusions, i.e., the application of documentary films is very effective in fostering the critical thinking skills of class X SMA Negeri 10 Sidenreng Rappang, showed by the result gained from the experimental group X IPA 1 compared to the control group X IPA 2. It was revealed that the average value of the experimental group was higher than the control group in developing critical thinking skills, which is means this present study believed that documentary films could foster students' critical thinking skills.

\section{References}

Ambrusius Kuncoro Brahmowisang, (2019). penerapan problem based learning $(P B L)$ dengan media film dokumenter pada pembelajaran sejarah untuk meningkatkan kemampuan berpikir kritis dan prestasi belajar siswa kelas XI IPS 2 SMAN 1 Wuryantoro.

Arief S. Sadiman, dkk. (2010). Media Pendidikan. Jakarta : PT Raja Grafindo Persada.

Aswadi, A., Rafi'uddin, A., Dawud, \& Basuki, I. A. (2021). Argument Pattern in Student Argumentative Essays in Higher Education Using the Toulmin Model. Psychology and Education, 58(3), 1046-1055.

Beyer, B.K. (1995). Critical Thinking. Bloominton. IN : Phi Delta Kappa Educational Foundation.

Chance, P. (1986). Thinking in the classroom: A survey of programs. New York: Teachers College, Columbia University.

Conny Dianoviana Siregar, 2013 Kemampuan Berpikir Kritis Siswa SMA Melalui Pembelajaran Guiden Enquiry Pada Sumkonsep Pencemaran Air Universitas Pendidikan Indonesia | repository.upi.edu | perpustakaan.upi.edu. 2745.

Ennis, Robert H. 1962. A concept of critical thinking. Harvard Educational Review, Vol 32(1), 81-111.

Fridanianti, A., Purwati, H., \& Murtianto, Y. H. (2018). Analisis Kemampuan Berpikir Kritis Dalam Menyelesaikan Soal Aljabar Kelas Vii SMP N 2 Pangkah Ditinjau Dari Gaya Kognitif Reflektif Dan Kognitif Impulsif. AKSIOMA: Jurnal Matematika Dan Pendidikan Matematika, 9(1), 11. https://doi.org/10.26877/aks.v9i1.2221.

Halpern, Diane F. (1989). Thought and knowledge: An introduction to critical thingking (end ed). Hillsdale, NJ, England : Lawrence Erlbaum Associates, Inc. XVII 517.PP.

Hamalik, Oemar. 1986. Media Pendidikan. Bandung: Alumni.

Hossoubah, Z. (2007). Develoving Creative and Critical Thinking Skills (terjemahan). Bandung: Yayasan Nuansa Cendia.

Kemp, J.E. dan Dayton, D.K. 1985. "Planning and producing instructional media”. Cambridge: Harper \& Row Publisher, New York. 
Lamalla, B., Hanafi, M., \& Ecca, S. (2019). Pengaruh Penggunaan Aplikasi Sparkol Videoscribe Terhadap Kemampuan Menyimak Siswa. 5151(2), 9-12.

Lanta, J. (2015). Pengajaran Cerpen melalui Strategi Multiple Intelliences di Sekolah Menengah. Seminar Internasional Bahasa, Sastra Dan Pembelajarannya, 147.

Mertes (1991). Thinking and Writing. Middle School Journ. 22:24-25.

Ririantika, R., M, U., Aswadi, A., \& Sakkir, G. (2020). Penerapan Model Pembelajaran Tipe "Make A Match" Terhadap Hasil Belajar Bahasa Indonesia. Cakrawala Indonesia, 5(1), 1-6.

Setiawan, W. (2015). Meningkatkan Kemampuan Berpikir Kritis Matematis Siswa Smp Dengan Menggunakan Model Penemuan Terbimbing. $P 2 M \quad$ STKIP Siliwangi, 2(1), 91. https://doi.org/10.22460/p2m.v2i1p91-97.168

Sugiyono. (2004). Statistika Untuk Penelitian. Bandung: Alfabeta.

Wening Astuti. 2014. Pemanfaatan Multimedia Interaktif Dalam Pembelajaran Matematika Untuk Meningkatkan Kemampuan Berpikir Kritis Dan Kreatif. Universitas Pendidikan Indonesia. Repository.upi.edu

perpustakaan.upi.edu. 